\title{
Characterization of the Rumen-Mimetic Continuous Cultivation System for Volatile Fatty Acid Production from Lignocellulosic Biomass
}

\author{
Hitosi Agematu ${ }^{1, *}$, Jun Watanabe ${ }^{2}$, Takehiko Takahashi ${ }^{3}$ \\ ${ }^{1}$ Department of Applied Chemistry, Akita National College of Technology, Akita, Japan \\ ${ }^{2}$ Department of Agribusiness, Akita Prefectural University, Ohgata, Japan \\ ${ }^{3}$ Department of Machine Intelligence and Systems Engineering, Akita Prefectural University, Yurihonjo, Japan \\ Email address: \\ agematu@akita-nct.ac.jp (H. Agematu) \\ ${ }^{*}$ Corresponding author
}

\section{To cite this article:}

Hitosi Agematu, Jun Watanabe, Takehiko Takahashi. Characterization of the Rumen-Mimetic Continuous Cultivation System for Volatile Fatty Acid Production from Lignocellulosic Biomass. International Journal of Microbiology and Biotechnology. Vol. 6, No. 1, 2021 , pp. 1-8. doi: $10.11648 /$ j.ijmb.20210601.11

Received: January 31, 2021; Accepted: February 7, 2021; Published: February 23, 2021

\begin{abstract}
The rumen-mimetic continuous cultivation system (RMS) was used to produce volatile fatty acids (VFAs), such as acetic, propionic, and butyric acids, from lignocellulosic biomass. Typical 12 species of ruminal bacteria were detected in the culture broth cultivated by RMS using species-specific PCR assay. These species are known to be cellulolytic, hemicellulolytic, proteolytic, amylolytic, and lipolytic bacteria and methanogens. Therefore, RMS was characterized to be ruminal fermentation like the digestive system of roughage in the rumen of cattle. Using RMS, the ruminal bacteria were continuously cultivated for 120 days to produce VFAs. The yield of total VFAs from $20-50 \mu \mathrm{m}$ rice straw was $167 \%$ higher than that from $300-1000 \mu \mathrm{m}$ rice straw. However, the productivity was not increased by pulverization of the substrate. The yield and productivity of acetic acid from $20-50 \mu \mathrm{m}$ rice straw were $0.147 \mathrm{~g} / \mathrm{g}$ and $34.8 \mathrm{mg} / \mathrm{L} / \mathrm{h}$, respectively, and those of propionic acid were $0.104 \mathrm{~g} / \mathrm{g}$ and 24.6 $\mathrm{mg} / \mathrm{L} / \mathrm{h}$, respectively. The selectivity (P/A ratio) of acetic and propionic acid production from microcrystalline cellulose at $\mathrm{pH}$ 6.5 and 7.0 were $0.83 \pm 0.07$ and $0.31 \pm 0.03$, respectively. The ruminal bacteria could not continue to produce VFAs at $p H$ 6.0. The yield and productivity of acetic acid from microcrystalline cellulose at $\mathrm{pH} 6.5$ were $0.234 \mathrm{~g} / \mathrm{g}$ and $51.7 \mathrm{mg} / \mathrm{L} / \mathrm{h}$, respectively, and those of propionic acid were $0.223 \mathrm{~g} / \mathrm{g}$ and $49.3 \mathrm{mg} / \mathrm{L} / \mathrm{h}$, respectively. This study proposes that in order to increase the productivity of RMS, it is necessary to increase the ruminal bacterial biomass by recycling biomass (flocs) using a settling tank.
\end{abstract}

Keywords: Rumen, Ruminal Bacteria, Volatile Fatty Acid, Acetic Acid, Propionic Acid, Lignocellulosic Biomass

\section{Introduction}

Lignocellulose is the main constituents in most plants and is comprised of cellulose $(40 \%-60 \%)$, hemicellulose $(20 \%-$ $30 \%)$, and lignin (15\%-30\%). It is the most abundant biomass on earth. Lignocellulosic biomass is classified into four groups based on the resource: (i) municipal solid waste, (ii) agricultural residues, (iii) forest residues, and (iv) wastepaper [1]. They are inexpensive, renewable, and available everywhere. The utilization of lignocellulosic biomass has become one of the most important avenues of research in the global shift from fossil fuels to renewable resources. Lignocellulosic biomass can be converted into more than a hundred different chemicals [2]. Among them volatile fatty acids (VFAs; mainly acetic, propionic, and butyric acids) are widely used as building block chemicals, which are employed in the manufacturing of a wide range of chemicals, pharmaceuticals, and biopolymers [1]. Therefore, biological VFAs production from lignocellulosic biomass has drawn extensive research interests to facilitate transition from an oil-based to a bio-based economy [1, 3]. However, it is economically limited by high downstream purification cost [4]. It is essentially important to produce VFAs from cheaper materials with lower purification cost. To reduce the purification cost, a fermentation broth from which VFAs can be purified at a low cost is needed. Biological VFAs 
production will be addressed if the target yield, productivity, and concentration of VFAs and less by-product fermentation can be achieved in the bioprocess.

The rumen-mimetic continuous cultivation system (RMS), including an energy-saving pulverization method of the substrate, has been proposed as a bioprocess to produce VFAs from lignocellulosic biomass [5, 6]. RMS is an anaerobic continuous cultivation system operated under well-defined conditions. The anaerobic process is easy to scale-up because the process does not need sterilization and ventilation. The flow rate is controlled to maintain broth $\mathrm{pH}$ at 6.50 by the addition of basic artificial saliva (mineral salts solution). The digestion of substrate is conducted in a batch type fermentation process because the substrate is an insoluble solid having a specific gravity heavier than water. RMS is a mixed culture fermentation process using the rumen fluid of cattle as an inoculum. However, the microbial community structure of RMS has not yet been completely analyzed. The diversity of ruminal bacteria is known to be highly responsive to a wide spectrum of substrates [7]. The cross feeding among ruminal bacteria results in a relatively more complete conversion of lignocellulosic biomass into the final fermentation products of VFAs [8]. Therefore, if it could be confirmed that RMS recreates the same conditions as observed during the digestive process in the rumen of cattle, namely ruminal fermentation, then the high yield and productivity of VFAs and the diversity of substrate could be expected from RMS.

In this study, to analyze the microbial community structure of ruminal bacteria cultivated by RMS, the PCR assays targeting species-specific regions of $16 \mathrm{~S}$ rDNA and genes were carried out. The effect of pulverization of substrate on the yield and productivity of VFAs was estimated. To optimize cultivation conditions, the effect of controlled $\mathrm{pH}$ on the selectivity of VFAs production was investigated. Furthermore, the response of ruminal bacteria to the conditions without feeding on nitrogen source was examined.

\section{Materials and Methods}

\subsection{Sampling of Rumen Fluid}

All experimental protocols were approved by the Animal Care and Use Committee of Akita Prefectural University (Ohgata, Akita, Japan). In this study, a Japanese shorthorn non-pregnant and non-lactating cow was used as the donor animal for ruminal fluid. The cow was fed $5 \mathrm{~kg}$ of hay (dry matter [DM] basis) and $0.65 \mathrm{~kg}$ of concentrate mixture (corn, buckwheat, barley, rice bran, and soybean meal; DM basis) twice daily, at 8:30 and 16:00. Approximately $1 \mathrm{~L}$ of rumen fluid was anaerobically collected from the cow using a stainless-steel oral catheter for cattle (Sanshin Industrial Co. Ltd., Kanagawa, Japan). The bottle was immediately filled with $\mathrm{O}_{2}$-free $\mathrm{CO}_{2}$ gas and was maintained at $39^{\circ} \mathrm{C}$. The rumen fluid was then transferred to the laboratory in Akita National College of Technology within $1 \mathrm{~h}$.

\subsection{Continuous Cultivation of Ruminal Bacteria Using RMS}

The experimental conditions of RMS have been described in previous articles $[5,6]$. Briefly, the cultivation was carried out anaerobically by intermittent ventilation with nitrogen gas at an incubation temperature of $39^{\circ} \mathrm{C}$ and the contents in the reactor were agitated at 30-40 rpm using impellers. The cultivation was simultaneously carried out in reactor A and B using $0.5 \mathrm{~L}$ of rumen fluid as a seed. The working volume of reactor A and B was 2.0 L. Twenty grams of microcrystalline cellulose (102331; Merck KGaA, Darmstadt, Germany; 20 $160 \mu \mathrm{m}[\geq 80 \%])$ or lignocellulosic biomass powder, such as rice straw and alfalfa hay, was continuously added to the reactor to produce VFAs. These additions were carried out when the substrate was completely digested and the medium $\mathrm{pH}$ increased above controlled $\mathrm{pH}$ levels. Pulverized alfalfa hay was fed once in approximately 20 days to supplement trace nutrients for ruminal bacteria, when continuous cultivation was carried out using microcrystalline cellulose as the sole carbon source. During fermentation, the $\mathrm{pH}$ of the culture solution was automatically controlled so as to not fall below 6.0, 6.5, or 7.0 (representing individual reaction conditions) by addition of basic artificial saliva containing bicarbonate, phosphate, urea, and ammonium. Simultaneously, the same volume of culture suspension was withdrawn from the reactor as an effluent. To analyze the microbial community structure in the reactor, about $10 \mathrm{~mL}$ of the reactor contents was collected before each feeding of substrate and was preserved at $-20^{\circ} \mathrm{C}$. All equipment and substrates were not sterilized.

\subsection{Pulverization of Substrates}

Rice straw and alfalfa hay were pulverized using a WB-1 blender (WARING, Torrington, USA) or a vibration mill using cog-ring media, called a tandem-ring mill [9, 10], under dry conditions. The rice straw pulverized by a WB-1 blender was separated into 300-1000 $\mu \mathrm{m}, 100-300 \mu \mathrm{m}$, and less than $100 \mu \mathrm{m}$, based on its particle size using a sieve. The average particle diameter of the rice straw pulverized by a tandem-ring mill was $20-50 \mu \mathrm{m}$. The productivity $(\mathrm{g} / \mathrm{L} / \mathrm{h})$ was expressed by product $(\mathrm{g})$ per working volume (L) per digestion time $(\mathrm{h})$.

\subsection{Cultivation Without Feeding on Nitrogen Source}

To investigate the effect of nitrogen source feeding on VFA production, the artificial saliva without nitrogen sources, namely urea and ammonium sulfate, was used to control the broth $\mathrm{pH}$ at 6.5 . Twenty grams of microcrystalline cellulose was added to reactor A and B every 24 hours as a supply of carbon source, ensuring that it does not become a limiting factor for VFAs production. Twenty grams of alfalfa hay powder was added to the reactors after 6 days as a nitrogen source. The amounts of VFAs produced every 24 hours were determined. 


\subsection{High-Performance Liquid Chromatography (HPLC) Analysis}

Acetic, propionic, and butyric acids in the effluent from the reactor were quantified by HPLC. The HPLC conditions and preparation of HPLC sample have been described in previous articles $[5,6]$.

\subsection{Bacterial DNA Extraction}

Total DNA was extracted from the rumen fluid collected from the cow and the reactor contents collected using an ISOPLANT II DNA extraction kit (Nippon Gene Co. Ltd., Tokyo, Japan) according to the manufacturer's instructions. The quantity and quality of the extracted DNA were verified by measuring the absorbance at 260 and $280 \mathrm{~nm}$ using a spectrophotometer, and the final concentration of DNA was adjusted to $10 \mathrm{ng} / \mu \mathrm{L}$ for DNA amplification through polymerase chain reaction (PCR).

\subsection{S rDNA PCR-amplification}

Seventeen species-specific PCR primer pairs, used to amplify partial 16S rDNA [11-14] and nifH gene [15] regions, and two genus-specific PCR primer pairs [14] were chosen (Table 1). A reaction mixture containing 20 pmol of each primer, $50 \mathrm{ng}$ of template DNA, and $20 \mu \mathrm{L}$ of Emerald Amp PCR master mix (Takara Bio INC., Shiga, Japan) in a total volume of $40 \mu \mathrm{L}$ was prepared. PCR was performed by GeneAtlas 322 (ASTEC CO. LTD., Fukuoka, Japan) using the following temperature settings: an initial denaturation at $94{ }^{\circ} \mathrm{C}$ for $6 \mathrm{~min}$, followed by 40 cycles of denaturation at $94{ }^{\circ} \mathrm{C}$ for $30 \mathrm{~s}$, annealing at the temperature indicated for the primer pair (Table 1) for $30 \mathrm{~s}$, and extension at $72{ }^{\circ} \mathrm{C}$ for $30 \mathrm{~s}$. A final extension step at $72{ }^{\circ} \mathrm{C}$ was carried out for $10 \mathrm{~min}$. The amplicons were examined by electrophoresis on $2.0 \%(\mathrm{w} / \mathrm{v})$ agarose gels. Gels were stained with SYBR Green I (Takara Bio INC., Shiga, Japan) according to manufacturer's instructions and photographed with UV transillumination using a Gel Doc EZ System (Bio-Rad Laboratories, Inc., CA, USA).

\subsection{Metabolic Flux Analysis of VFAs Production from Cellulose}

The cell biomass of continuous cultivation is in a stationary phase. If the carbohydrate converted to microbial organic matter is ignored, the amounts of certain catabolic products can be stoichiometrically calculated from the molar productions of VFAs using "fermentation balance" [16]. When the productions of acetic, propionic, and butyric acids from $1 \mathrm{~g}$ of substrate are $\mathrm{A}, \mathrm{P}$, and $\mathrm{B}$ mmol, respectively, the values are calculated as follows:

Total VFAs yield $(\mathrm{mmol} / \mathrm{g})$ is $\mathrm{A}+\mathrm{P}+\mathrm{B}$.

Glucose used $(\mathrm{mmol} / \mathrm{g})$ is $0.5 \mathrm{~A}+0.5 \mathrm{P}+\mathrm{B}$.

Cellulose used $(\mathrm{g} / \mathrm{g})$ is $(0.5 \mathrm{~A}+0.5 \mathrm{P}+\mathrm{B}) \times 0.162$.

Carbon dioxide yield $(\mathrm{mmol} / \mathrm{g})$ is $0.5 \mathrm{~A}+0.25 \mathrm{P}+1.5 \mathrm{~B}$.

Methane yield $(\mathrm{mmol} / \mathrm{g})$ is $0.5 \mathrm{~A}-0.25 \mathrm{P}+0.5 \mathrm{~B}$.

$\mathrm{NADH}$ generated $(\mathrm{mmol} / \mathrm{g})$ is $2 \mathrm{~A}-\mathrm{P}+2 \mathrm{~B}$.
ATP yield $(\mathrm{mmol} / \mathrm{g})$ is $2.5 \mathrm{~A}+2.75 \mathrm{P}+3.5 \mathrm{~B}$.

Potential microbial yield $(\mathrm{g} / \mathrm{g})$ is $25 \mathrm{~A}+27.5 \mathrm{P}+35 \mathrm{~B}$ (using $10 \mathrm{~g}$-cell/mol-ATP).

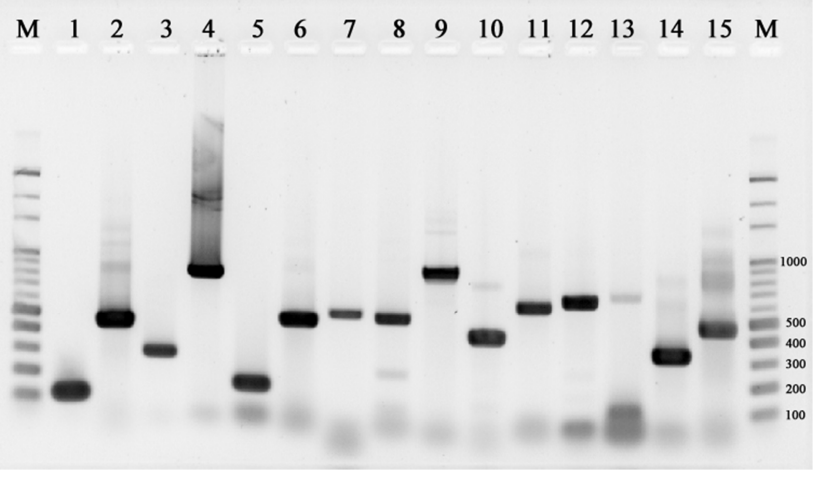

Figure 1. Amplification of rumen bacterial DNA with the primer set detailed in Table 1. Lanes (size [bp]): 1, Fibrobacter succinogenes (120); 2, Fibrobacter succinogenes (446); 3, Ruminococcus flavefaciens (295); 4, Ruminococcus flavefaciens (835); 5, Ruminococcus albus (175); 6, Prevotella ruminicola (485); 7, Prevotella bryantii (540); 8, Selenomonas ruminantium (513); 9, Streptococcus bovis (869); 10, Treponema bryantii (421); 11, Anaerovibrio lipolytica (597); 12, Ruminobacter amylophilus (642); 13, Eubacterium ruminantium (671); 14, Methanobrevibacter ruminantium (336); 15, methanogen (414-438). Lane M, DNA size marker.

\section{Results}

\subsection{Species-specific PCR Assays for Ruminal Bacteria}

Ruminal bacteria were continuously cultivated for 120 days by RMS. Fourteen species-specific primer pairs recognizing 12 species of ruminal bacteria amplified the target DNA fragments from bacterial DNA extracts, while 3 primer pairs did not (Table 1). The sizes of PCR products were as expected (Figure 1). Therefore, 12 species of ruminal bacteria were detected in the culture broth. The target DNA product for Succinivibrio dextrinosolvens could not be detected after 12 days of cultivation. The primer pairs for Prevotella albensis and Megasphaera elsdenii did not amplify target sequences even from the total DNA extract of rumen fluid used as a seed. The other amplified target DNA products were detected until the end of cultivation.

\subsection{Effect of Pulverization of Substrate}

Twenty grams of pulverized rice straw, of varying particle size, were added to the reactor to investigate the effect of pulverization of substrate on VFAs production (Table 2). The digestion time was the time between the addition of substrate and the end of its digestion indicated by rise in $\mathrm{pH}$ (Figure 2). The yield of acetic acid, propionic acid, and total VFAs from $300-1000 \mu \mathrm{m}$ rice straw were $0.104 \mathrm{~g} / \mathrm{g}, 0.045 \mathrm{~g} / \mathrm{g}$, and 2.46 $\mathrm{mmol} / \mathrm{g}$, respectively, while those from $20-50 \mu \mathrm{m}$ rice straw were $0.147 \mathrm{~g} / \mathrm{g}, 0.104 \mathrm{~g} / \mathrm{g}$, and $4.11 \mathrm{mmol} / \mathrm{g}$, respectively. The yield of total VFAs from $20-50 \mu \mathrm{m}$ rice straw was $167 \%$ higher than that from $300-1000 \mu \mathrm{m}$ rice straw. Therefore, the yield was increased by pulverization. The digestion time also increased due to pulverization. The productivity of acetic acid, propionic acid, and total VFAs from $300-1000 \mu \mathrm{m}$ rice straw 
Hitosi Agematu et al:: Characterization of the Rumen-Mimetic Continuous Cultivation System for Volatile Fatty Acid Production from Lignocellulosic Biomass

were $39.8 \mathrm{mg} / \mathrm{L} / \mathrm{h}, \quad 17.3 \mathrm{mg} / \mathrm{L} / \mathrm{h}$, and $0.94 \mathrm{mmol} / \mathrm{L} / \mathrm{h}$, respectively, while those from $20-50 \mu \mathrm{m}$ rice straw were 34.8

$\mathrm{mg} / \mathrm{L} / \mathrm{h}, 24.6 \mathrm{mg} / \mathrm{L} / \mathrm{h}$, and $0.97 \mathrm{mmol} / \mathrm{L} / \mathrm{h}$, respectively.

Table 1. PCR primers for detection of ruminal bacteria.

\begin{tabular}{|c|c|c|c|c|c|}
\hline Target species & Primer sequences (5'-3') & Annealing $\left({ }^{\circ} \mathbf{C}\right)$ & Size (bp) & Amplification $^{*}$ & Reference \\
\hline \multirow{2}{*}{ Fibrobacter succinogenes } & $\begin{array}{l}\text { F GTTCGGAATTACTGGGCGTAAA } \\
\text { R CGCCTGCCCCTGAACTATC }\end{array}$ & 60 & 120 & + & 11 \\
\hline & $\begin{array}{l}\text { F GGTATGGGATGAGCTTGC } \\
\text { R GCCTGCCCCTGAACTATC }\end{array}$ & 60 & 446 & + & 12,13 \\
\hline \multirow{2}{*}{ Ruminococcus flavefaciens } & $\begin{array}{l}\text { F TCTGGAAACGGATGGTA } \\
\text { R CCTTTAAGACAGGAGTTTACAA }\end{array}$ & 55 & 295 & + & 13 \\
\hline & $\begin{array}{l}\text { F GGACGATAATGACGGTACTT } \\
\text { R GCAATCYGAACTGGGACAAT }\end{array}$ & 62 & 835 & + & 12,13 \\
\hline Ruminococcus albus & $\begin{array}{l}\text { F CCCTAAAAGCAGTCTTAGTTCG } \\
\text { R CCTCCTTGCGGTTAGAACA }\end{array}$ & 55 & 175 & + & 13 \\
\hline Prevotella ruminicola & $\begin{array}{l}\text { F GGTTATCTTGAGTGAGTT } \\
\text { R CTGATGGCAACTAAAGAA }\end{array}$ & 53 & 485 & + & 12,14 \\
\hline Prevotella bryantii & $\begin{array}{l}\text { F ACTGCAGCGCGAACTGTCAGA } \\
\text { R ACCTTACGGTGGCAGTGTCTC }\end{array}$ & 65 & 540 & + & 12,14 \\
\hline Prevotella albensis & $\begin{array}{l}\text { F CAGACGGCATCAGACGAGGAG } \\
\text { R ATGCAGCACCTTCACAGGAGC }\end{array}$ & 68 & 861 & - & 12 \\
\hline Megasphaera elsdenii & $\begin{array}{l}\text { F GACCGAAACTGCGATGCTAGA } \\
\text { R CGCCTCAGCGTCAGTTGTC }\end{array}$ & 58 & 130 & - & 14 \\
\hline Selenomonas ruminantium & $\begin{array}{l}\text { F TGCTAATACCGAATGTTG } \\
\text { R TCCTGCACTCAAGAAAGA }\end{array}$ & 57 & 513 & + & 14 \\
\hline Streptococcus bovis & $\begin{array}{l}\text { F GACCGAAACTGCGATGCTAGA } \\
\text { R CGCCTCAGCGTCAGTTGTC }\end{array}$ & 57 & 869 & + & 12,14 \\
\hline Treponema bryantii & $\begin{array}{l}\text { F AGTCGAGCGGTAAGATTG } \\
\text { R CAAAGCGTTTCTCTCACT }\end{array}$ & 57 & 421 & + & 12,14 \\
\hline Anaerovibrio lipolytica & $\begin{array}{l}\text { F TGGGTGTTAGAAATGGATTC } \\
\text { R CTCTCCTGCACTCAAGAATT }\end{array}$ & 58 & 597 & + & 12,14 \\
\hline Ruminobacter amylophilus & $\begin{array}{l}\text { F CAACCAGTCGCATTCAGA } \\
\text { R CACTACTCATGGCAACAT }\end{array}$ & 57 & 642 & + & 12,14 \\
\hline Succinivibrio dextrinosolvens & $\begin{array}{l}\text { F TGGGTGTTAGAAATGGATTC } \\
\text { R CTCTCCTGCACTCAAGAATT }\end{array}$ & 58 & 854 & - & 12,14 \\
\hline Eubacterium ruminantium & $\begin{array}{l}\text { F GCTTCTGAAGAATCATTTGAAG } \\
\text { R TCGTGCCTCAGTGTCAGTGT }\end{array}$ & 57 & 671 & + & 12 \\
\hline $\begin{array}{l}\text { Methanobrevibacter } \\
\text { ruminantium (nifH gene) }\end{array}$ & $\begin{array}{l}\text { F AATATTGCAGCAGCTTACAGTGAA } \\
\text { R TGAAAATCCTCCGCAGACC } \\
\text { F GGTGGTGTMGGATTCACACARTAYGCWA }\end{array}$ & 63 & 336 & + & 15 \\
\hline Methanogen ( $m c r A$ gene) & $\begin{array}{l}\text { CAGC } \\
\text { R TTCATTGCRTAGTTWGGRTAGTT }\end{array}$ & 55 & $414-438$ & + & 14 \\
\hline Genus Prevotella & $\begin{array}{l}\text { F CACRGTAAACGATGGATGCC } \\
\text { R GGTCGGGTTGCAGACC }\end{array}$ & 55 & 534 & + & 14 \\
\hline
\end{tabular}

F, forward primer; R, reverse primer. " this study.

Table 2. Production of acetic, propionic, and butyric acids from $20 \mathrm{~g}$ of pulverized rice straw.

\begin{tabular}{lllllll}
\hline $\begin{array}{l}\text { Particle size }(\boldsymbol{\mu m}) \\
\left(\mathbf{n}^{\mathbf{2}}\right)\end{array}$ & $\begin{array}{l}\text { Digestion time } \\
(\mathbf{h})\end{array}$ & Effluent $(\mathbf{m l})$ & $\begin{array}{l}\text { Acetic acid } \\
(\mathbf{m m o l})\end{array}$ & Propionic acid $(\mathbf{m m o l})$ & $\begin{array}{l}\text { Butyric acid } \\
(\mathbf{m m o l})\end{array}$ & $\begin{array}{l}\text { Total VFAs } \\
(\mathbf{m m o l})\end{array}$ \\
\hline $300-1000(3)$ & $26.1 \pm 5.3$ & $465 \pm 90$ & $34.6 \pm 7.4$ & $12.2 \pm 2.5$ & $2.3 \pm 0.4$ & $49.1 \pm 10.3$ \\
$100-300(4)$ & $53.2 \pm 6.1$ & $579 \pm 59$ & $40.5 \pm 5.2$ & $18.5 \pm 3.1$ & $2.9 \pm 0.3$ & $61.8 \pm 8.4$ \\
$<100(3)$ & $41.2 \pm 2.0$ & $642 \pm 12$ & $52.1 \pm 3.0$ & $15.7 \pm 0.8$ & $3.2 \pm 0.1$ & $71.0 \pm 3.6$ \\
$20-50^{\mathrm{c}}(3)$ & $42.3 \pm 0.9$ & $803 \pm 40$ & $49.0 \pm 4.1$ & $28.1 \pm 1.3$ & $5.0 \pm 0.1$ & $82.1 \pm 5.3$ \\
\hline
\end{tabular}

Values represent means \pm SE. ${ }^{a}$ Numbers of separate trials; ${ }^{b}$ Total VFAs is the combined amount of acetic, propionic, and butyric acids; ${ }^{\mathrm{c}}$ Average particle diameter.

The productivity of total VFAs was not increased by pulverization.

\subsection{Effect of Cultivation $\mathrm{pH}$}

Ruminal bacteria were cultivated at $\mathrm{pH} 6.0,6.5$, or 7.0 to produce VFAs from 20 grams of microcrystalline cellulose. The amounts of produced VFAs were determined (Table 3 ). Ruminal bacteria stably produced VFAs at $\mathrm{pH} 6.5$ and 7.0. The amounts of total VFAs produced at $\mathrm{pH} 6.5$ and 7.0 were almost the same, while the selectivity (P/A ratio [ $\mathrm{mol} / \mathrm{mol}])$ of acetic acid and propionic acid production at $\mathrm{pH} 6.5$ and 7.0 were $0.83 \pm 0.07$ and $0.31 \pm 0.03$, respectively. The $\mathrm{P} / \mathrm{A}$ ratio depended on the cultivation $\mathrm{pH}$. The yield, productivity, and concentration of acetic acid at $\mathrm{pH} 6.5$ were $0.234 \mathrm{~g} / \mathrm{g}, 51.7$ $\mathrm{mg} / \mathrm{L} / \mathrm{h}$, and $3.43 \mathrm{~g} / \mathrm{L}$, respectively, while those of propionic acid at $\mathrm{pH} 6.5$ were $0.223 \mathrm{~g} / \mathrm{g}, 49.3 \mathrm{mg} / \mathrm{L} / \mathrm{h}$, and $3.28 \mathrm{~g} / \mathrm{L}$, respectively. The yield of methane produced theoretically at $\mathrm{pH} 6.5$ and 7.0 was 1.50 and $2.48 \mathrm{mmol} / \mathrm{g}$, respectively. It is 
obvious from the metabolic flux analysis described in materials and methods section that propionic acid production and methane production are inversely related.

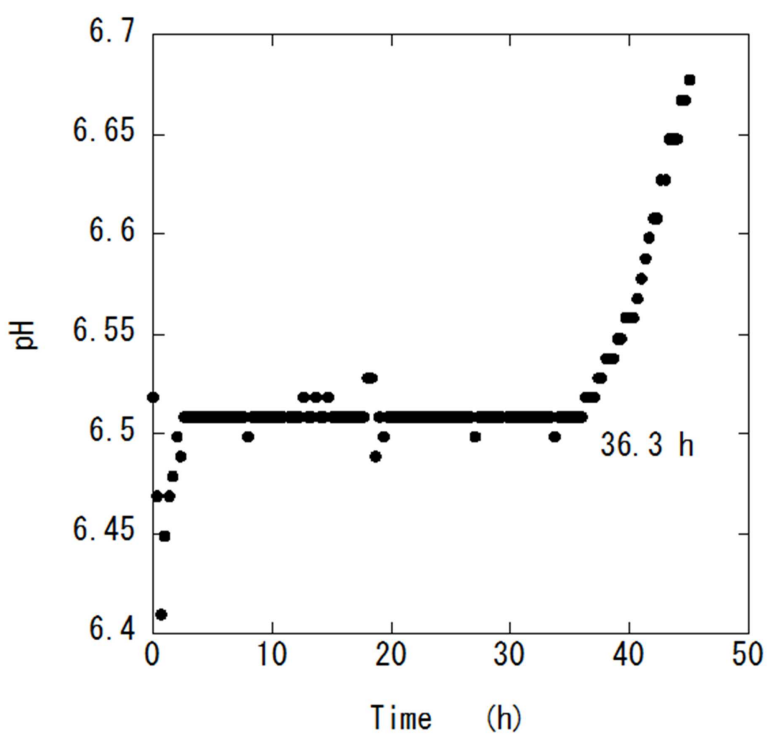

Figure 2. Typical pH pattern observed during the digestion of substrate. The rice straw $(20 \mathrm{~g})$ pulverized less than $100 \mu \mathrm{m}$ was added to the reactor. The $\mathrm{pH}$ was regulated so as not to decrease below 6.50 via the automatic addition of the artificial saliva. The $\mathrm{pH}$ value increased above 6.50 after $36.3 \mathrm{~h}$ when the digestion of rice straw ended. The digestion time of the rice straw was 36.3 $h$.

The concentration of total VFAs in the reactor was $106 \pm 2.2$ $\mathrm{mM}$, depending on the buffering action of artificial saliva. In the cultivation at $\mathrm{pH} 6.0$, the VFAs production ceased after $150 \mathrm{~h}$ of the cultivation (Figure 3). Twenty grams of microcrystalline cellulose was added in the reactor (arrows 1, 2, and 3 shown in Figure 3) when the digestion of substrate ended, following by an increase in $\mathrm{pH}$ value above 6.0. The $\mathrm{pH}$ value decreased rapidly by the first (arrow 1) and the second (arrow 2) addition because of VFAs production. However, in the third (arrow 3 ) addition, the $\mathrm{pH}$ value did not decrease. This phenomenon indicated that ruminal bacteria could no longer produce VFAs.

\subsection{Cultivation Without Feeding on Nitrogen Source}

When feeding of nitrogen source was stopped, the amount of total VFAs produced in $24 \mathrm{~h}$ gradually decreased with cultivation time. However, VFA production continued for 6 days. When 20 grams of alfalfa hay was fed on the sixth day, the VFA production recovered sharply (Figure 4).

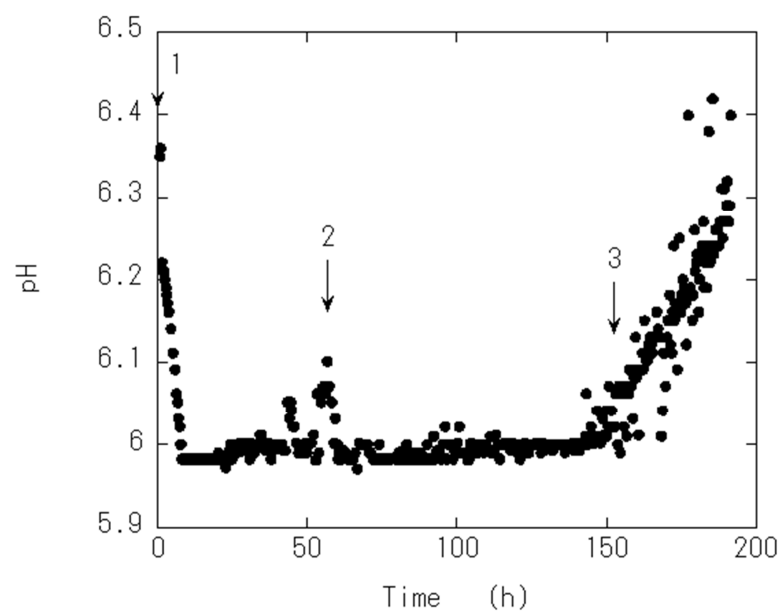

Figure 3. $\mathrm{pH}$ pattern observed during cultivation of ruminal bacteria at $\mathrm{pH}$ 6.0.

\section{Discussion}

We have previously analyzed the microbial community structure of RMS using PCR denaturing gradient gel electrophoresis (PCR-DGGE) assay, showing that the structure was relatively stable, and identified three rumen bacterial species: Fibrobacter succinogenes, Prevotella ruminicola, and Succiniclasticum ruminis [5]. However, the similarities of the 16S rDNA sequences of the other DGGE bands with those of known isolates were less than $90 \%$ according to BLAST searches of the GenBank database. The ruminal bacterial community appears to include a considerable proportion of unidentified bacteria [17]. Therefore, species-specific PCR assays were used to analyze the microbial community structure in this study. Furthermore, we have shown that ruminal bacteria formed flocs and biofilms on the surface of substrate to construct their community [5].

Twelve species of ruminal bacteria (1-12) detected by PCR assays are involved in the fermentation from cellulose to VFAs as shown in Figure 5. F. succinogenes (1), Ruminococcus flavefaciens (2), and Ruminococcus albus (3) are representative cellulolytic bacteria of the rumen [18]. All three bacteria were detected in the culture broth of the reactor. Initially, they break down cellulose into glucose. This hydrolysis is a rate-limiting step of VFAs production. They need symbiotic relationships with proteolytic bacteria because all three species are not proteolytic [8].

Table 3. Production of acetic, propionic, and butyric acids from $20 \mathrm{~g}$ of microcrystalline cellulose at pH 7.0, 6.5, or 6.0.

\begin{tabular}{|c|c|c|c|c|c|c|c|}
\hline pH $\left(n^{a}\right)$ & $\begin{array}{l}\text { Digestion } \\
\text { time (h) }\end{array}$ & Effluent (ml) & $\begin{array}{l}\text { Acetic acid } \\
\text { (mmol) }\end{array}$ & $\begin{array}{l}\text { Propionic acid } \\
\text { (mmol) }\end{array}$ & $\begin{array}{l}\text { Butyric acid } \\
\text { (mmol) }\end{array}$ & $\begin{array}{l}\text { Total VFAs } \\
\text { (mmol) }\end{array}$ & $\begin{array}{l}\text { P/A ratio } \\
(\mathrm{mol} / \mathrm{mol})\end{array}$ \\
\hline $7.0(8)$ & $45.1 \pm 4.6$ & $1471 \pm 104$ & $105.8 \pm 8.5$ & $33.5 \pm 4.1$ & $10.2 \pm 1.0$ & $149.5 \pm 13.0$ & $0.31 \pm 0.03$ \\
\hline $6.5(11)$ & $48.3 \pm 2.9$ & $1371 \pm 54$ & $77.9 \pm 6.0$ & $60.3 \pm 2.8$ & $12.1 \pm 1.2$ & $150.4 \pm 8.4$ & $0.83 \pm 0.07$ \\
\hline $6.0(2)$ & 72.7 & 1000 & 65.1 & 48.9 & 10.4 & 124 & 0.77 \\
\hline
\end{tabular}

Values represent means \pm SE. ${ }^{a}$ Numbers of separate trials, ${ }^{b}$ Total VFAs is the combined amount of acetic, propionic, and butyric acids.

${ }^{\mathrm{c}} \mathrm{P} / \mathrm{A}$ ratio=propionic acid $(\mathrm{mmol}) /$ acetic acid $(\mathrm{mmol})$ 


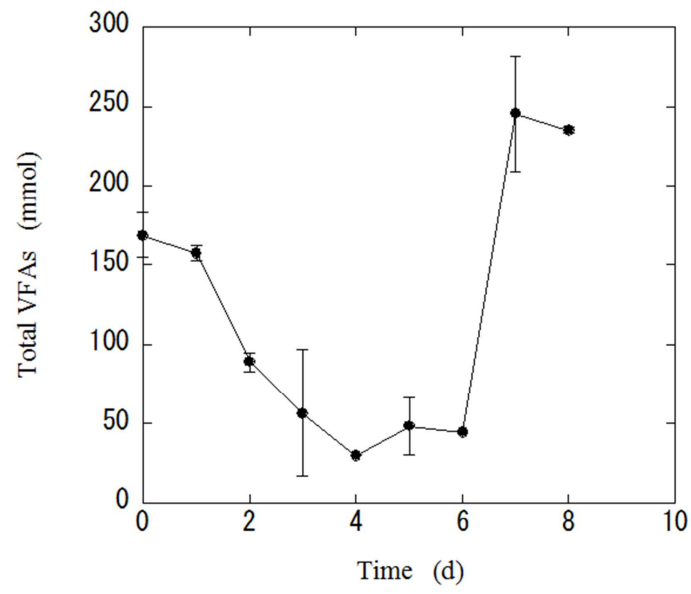

Figure 4. Production of total VFAs in the cultivation condition without feeding on nitrogen source. Alfalfa hay powder $(20 \mathrm{~g})$ was fed on sixth day.

P. ruminicola (4) [19], Selenomonas ruminantium (6) [20], and Treponema bryantii (8) [21] are non-cellulolytic bacteria and have been reported to synergize with cellulolytic bacteria to promote cellulose digestion. P. ruminicola (4), Prevotella bryantii (8), and Eubacterium ruminantium (11) are non-cellulolytic bacteria, while they possess oligosaccharolytic and xylanolytic activities and occupy the second line of degraders of hemicellulose with cellulolytic bacteria [8]. The gram-negative microbes, Prevotella sp., $S$. ruminantium (6), and Ruminobacter amylophilus (10), and the gram-positive bacterium, Streptococcus bovis (7), are the main starch-utilizing, or amylolytic, bacteria and become abundant when ruminants ingest large amount of cereal grains [22]. It was shown that these amylolytic bacteria could be cultivated using cellulose as the sole carbon source by RMS. The genus Prevotella constitutes one of the most predominant genera in the rumen, with major roles in carbohydrate and nitrogen metabolism [23]. P. ruminicola (4) is considered to play a central role in carbohydrate and protein degradation in rumen [24]. P. bryantii (8) has been recognized as one of the predominant amylolytic bacteria in the rumen of animals fed high-concentrate diets and it grows rapidly on starch media to produce mainly succinate and propionate [25]. When $S$. ruminantium (6) was co-cultured with $F$. succinogenes (1), propionate production was enhanced. $S$. ruminantium (6) is a lactate-utilizing and succinate-utilizing bacterium [20]. S. bovis (7) has a very fast rate of fermentation to produce acetic acid, formic acid, and ethanol from glucose, but it can shift to homolactic fermentation if there is excessive fermentable carbohydrate, such as cereal grain starch, and the $\mathrm{pH}$ is lower than 5.6, because its lactate hydroxylase activity is most active at $\mathrm{pH} 5.5$ [26, 27]. However, the accumulation of lactate was not observed in this study because the culture broth $\mathrm{pH}$ was controlled above 6.5. T. bryantii (8) catabolizes glucose to acetate, formate, and succinate [28]. Anaerovibrio lipolytica (9) produces propionate and succinate from glycerol, and acetate and propionate from DL-lactate, and produces an extracellular lipase during exponential growth to hydrolyze triglycerides most rapidly [29]. E. ruminantium (11) produced butyrate from two molecules of acetyl coenzyme A (acetyl-CoA) [30]. Methanogenesis is a very important metabolic activity in the rumen microbial ecosystem to eliminate reducing equivalents produced by carbohydrate-fermenting bacteria, although it is an energy and metabolic loss in VFAs production. The detection of Methanobrevibacter ruminantium (12) (nifH) and methanogens ( $m c r A)$ using PCR assays showed that methanogenesis was stably maintained by RMS. $M$. ruminantium is one of the most common species of methanogens isolated from the rumen [31] and grows optimally from $\mathrm{pH} 6.3$ to 6.8 [32].

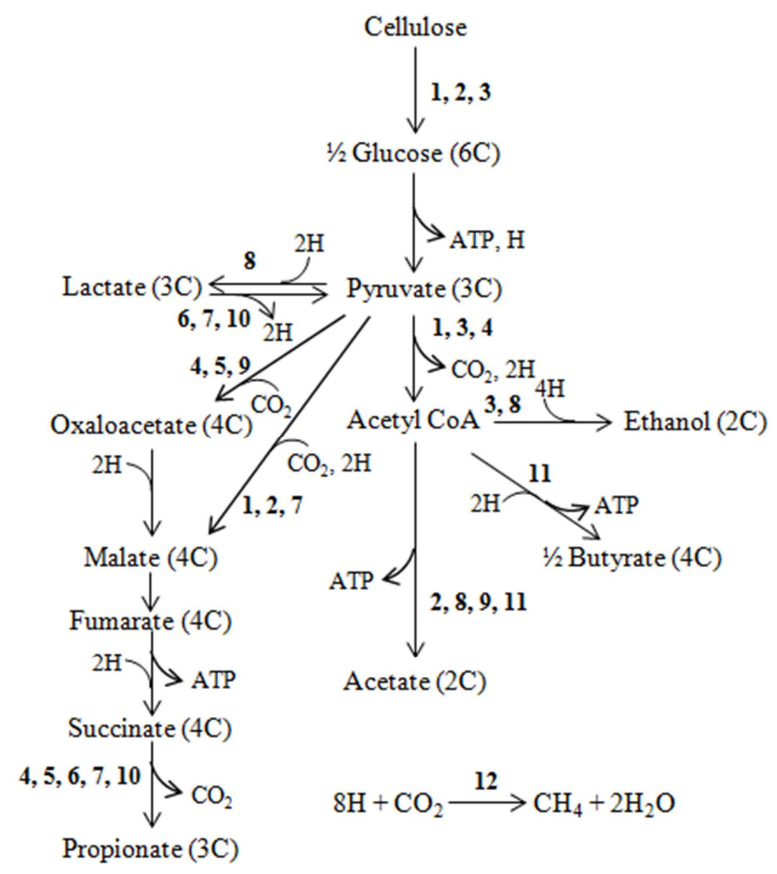

Figure 5. The roles of the detected ruminal bacteria in pyruvate metabolism and methanogenesis (adapted from [8]). 1, F. succinogenes; 2, R. flavefaciens; 3, R. albus; 4, P. ruminicola; 5, P. bryantii; 6, S. ruminantium; 7, S. bovis; 8, T. bryantii; 9, A. lipolytica; 10, R. amylophilus; 11, E. ruminantium; 12 , M. ruminantium.

It is important to increase accessibility of ruminal bacteria to lignocellulosic materials and accelerate their digestion. The pulverization of lignocellulosic biomass can not only increase its accessible surface area but also decrease the crystallinity of its cellulose to digest it easily [33]. In this study, the theoretically used cellulose of microcrystalline cellulose at $\mathrm{pH}$ 6.5 was $0.658 \mathrm{~g} / \mathrm{g}$ and the yield $(\mathrm{g} / \mathrm{g})$ was increased by pulverization of substrate (Table 2). Thus, high yield will be expected with RMS because digestible cellulose and hemicellulose contained in the substrate are completely digested by ruminal bacteria. Although the surface area of substrate was increased by pulverization, the productivity $(\mathrm{g} / \mathrm{L} / \mathrm{h})$ of the bioprocess was not increased. The result suggested that the rate-determining factor of productivity was bacterial biomass, and not surface area of the substrate. The productivity of VFAs depends on bacterial biomass when there is enough substrate for bacteria to digest. The bacterial 
biomass is almost constant in the steady state of continuous cultivation. Based on these considerations, the productivity of VFAs will be constant in most digestion time regardless of the amount of substrate. Therefore, the productivity was not increased by pulverization. To increase the productivity, it will be necessary to increase the ruminal bacterial biomass by feeding substrate containing crude protein to promote cell synthesis and/or recycling biomass (flocs) using a settling tank.

The final products of ruminal fermentation will vary according to microbiota, substrate type, substrate concentration, and fermentation conditions, particularly the $\mathrm{pH}$. The variation is basically due to metabolic pathways used by different populations of ruminal bacteria to get energy (ATP) from substrate (Figure 5). In the present study, although the amount of total VFAs produced at $\mathrm{pH} 7.0$ and 6.5 were almost the same, the amount of propionic acid at $\mathrm{pH} 6.5$ was more than that at $\mathrm{pH}$ 7.0. This result indicated that the activity of ruminal bacteria that metabolized pyruvate to propionate was higher than the ones metabolizing pyruvate to acetate at $\mathrm{pH} 6.5$, while the later was higher than the former at $\mathrm{pH}$ 7.0. The VFAs production did not continue at $\mathrm{pH} 6.0$ (Figure 3). This was because cellulolytic bacteria could not grow with a low intracellular $\mathrm{pH}$ [34]. Therefore, the operation at $\mathrm{pH} 6.5$ was chosen to produce more propionic acid from lignocellulosic biomass. The market price of propionic acid is 2.5 times higher than that of acetic acid [1]. Moreover, potential microbial yield $(\mathrm{g} / \mathrm{g})$ at $\mathrm{pH} 6.5$ is theoretically more than that at $\mathrm{pH} 7.0$ according to metabolic flux analysis. In another experiment using ruminal fluid collected from the same cow on another day, the $\mathrm{P} / \mathrm{A}$ ratio ( $\mathrm{mol} / \mathrm{mol}$ ) was $1.21 \pm 0.04$ (data not shown). The result showed that the variations in ruminal fluid collected from a cow also influenced $\mathrm{P} / \mathrm{A}$ ratio. Furthermore, it may be possible to increase $\mathrm{P} / \mathrm{A}$ ratio by increasing the population of succinate-utilizing bacteria (Figure 5).

Most of the ruminal bacteria can use ammonia as a nitrogen source [8]. Therefore, lignocellulosic biomass not containing a nitrogen source, such as wastepaper, can be digested by ruminal bacteria via supplying ammonium. Ruminal bacteria are known to lyse even when they are growing, independent of the growth rate [35]. A nitrogen source, which is necessary for their growth, is partially provided in the form of protein by autolysis. Thus, ruminal bacteria continued to produce VFAs for 6 days without feeding of nitrogen source (Figure 4). When alfalfa hay was fed on sixth day, the VFAs production resumed to initial levels immediately. The result showed that the cell mass of ruminal bacteria scarcely decreased even if nitrogen source feeding was stopped for 6 days.

\section{Conclusion}

All ruminal bacteria needed to produce VFAs, especially acetic acid and propionic acid, from lignocellulosic biomass were stably cultivated by RMS. Therefore, RMS is ruminal fermentation effectively producing VFAs. The vast array of knowledges about ruminal fermentation in the field of animal husbandry would help to understand the operating conditions of RMS and to develop an optimal operating strategy. The yield $(\mathrm{g} / \mathrm{g})$ was increased by pulverization of the substrate, while the productivity $(\mathrm{g} / \mathrm{L} / \mathrm{h})$ was not. To increase the productivity, it will be necessary to increase the ruminal bacterial biomass by feeding substrate containing crude protein to promote cell synthesis and/or recycling biomass (flocs) using a settling tank. The composition of VFAs production, namely $\mathrm{P} / \mathrm{A}$ ratio, depended on cultivation $\mathrm{pH}$. The cultivation at $\mathrm{pH} 6.5$ was suitable for propionic acid production. Because the ruminal bacteria digested most of the organic matter except for lignin to produce VFAs, carbon dioxide, and methane, the main water-soluble products in the effluent were VFAs. This is advantageous for purifying VFAs at a low cost and critical to downstream applications.

\section{Acknowledgements}

The authors thank Satoe Ozawa (Akita Prefectural University) for the breeding of cattle and the collection of ruminal fluid. This work was supported by MAFF (grant number: 27017B) and JSPS KAKENHI (grant number: 15K14701).

\section{References}

[1] Annamalai, N., Elayaraja, S., Oleskowicz-Popiel, P., Sivakumar, N., and Bahry, S. A. "Volatile fatty acids production during anaerobic digestion of lignocellulosic biomass" in Recent Developments in Bioenergy Research, Gupta, V. K., Treichel, H., Kuhad, R. C., and Rodrigues-Cout, S., Eds. Elsevier B. V., Amsterdam, 2020. pp. 237-251.

[2] Dusselier, M., Mascal, M., and Sels, B. F. (2014). Top chemical opportunities from carbohydrate biomass: A chemist's view of the biorefinery, Top Curr. Chem., 353.

[3] Baumann, I. and Westermann, P. (2016). Microbial production of short chain fatty acids from lignocellulosic biomass: current processes and market, Biomed Res. Int., 2016: 1-15.

[4] Gonzalez-Garcia, R. A., McCubbin, T., Navone, L., Stowers, C., Nielsen, L. K., and Marcellin, E. (2017). Microbial propionic acid production, Fermentation, 3: 1-21.

[5] Agematu, H., Takahashi, T., and Hamano, Y. (2017). Continuous volatile fatty acid production from lignocellulosic biomass by a novel rumen-mimetic bioprocess, J. Biosci. Bioeng., 124: 528-533.

[6] Agematu, H., Takahashi, T., and Hamano, Y. (2019). An in vitro rumen-mimetic continuous cultivation system for evaluating the nutritional value of micropulverized roughage based on volatile fatty acid production, Anim. Husb. Dairy Vet. Sci., 3: 1-8.

[7] Kocherginskaya, S. A., Aminov, R. I., and White, B. A. (2001). Analysis of the rumen bacterial diversity under two different diet conditions using denaturing gradient gel electrophoresis, random sequencing, and statistical ecology approaches, Anaerobe, 7: 119-134.

[8] Nagaraja, T. G. "Microbiology of the Rumen" in Rumenology, Millen, D. D., De Beni Arrigoni, M. and Lauritano Pacheco, R. D. Eds. Springer-International Publishing, Switzerland, 2016, pp. 39-61. 
[9] Takahashi, T. (2019). Scaled-up pulverizing for lignocellulose biomass using a vibratory mill with ring media, Renew. Energy, 144: $77-83$

[10] Takahashi, T., Ito, K., Ito, A., Enda, Y., Gochi, M., Mori, H., and Kobayashi, J. (2014). Tandem-ring mill pulverization benefits for enzymatic saccharification of biomass, Renew. Energy, 65: 146-151.

[11] Denman, S. E. and McSweeney, C. S. (2006). Development of a real-time PCR assay formonitoring anaerobic fungal and cellulolytic bacterial populations within the rumen, FEMS Microbiol. Ecol., 58: 572-582.

[12] Tajima, K., Aminov, R. I., Nagamine, T., Matsui, H., Nakamura, M., and Benno, Y. (2001). Diet-dependent shifts in the bacterial population of the rumen revealed with real-time PCR, Appl. Environ. Microbiol., 67: 2766-2774.

[13] Koike, S., Pan, J., Kobayashi, Y., and Tanaka, K. (2003). Kinetics of in sacco fiber-attachment of representative ruminal cellulolytic bacteria monitored by competitive PCR, J. Dairy Sci., 86: 1429-1435.

[14] Bekele, A. Z., Koike, S., and Kobayashi, Y. (2010). Genetic diversity and diet specificity of ruminal Prevotella revealed by16S rRNA gene-based analysis, FEMS Microbiol. Lett., 305: 49-57.

[15] Ufnar, J. A., Wang, S. Y., Ufnar, D. F., and Ellender, R. D. (2007). Methanobrevibacter ruminantium as an indicator of domesticated-ruminant fecal pollution in surface waters, Appl. Environ. Microbiol., 73: 7118-7121.

[16] Owens, F. N. and Basalan, M. "Ruminal Fermentation" in Rumenology, Millen, D. D., De Beni Arrigoni, M. and Lauritano Pacheco, R. D. Eds. Springer-International Publishing, Switzerland, 2016, pp. 63-102.

[17] Koike, S., Yoshitani, S., Kobayashi, Y., and Tanaka, K. (2003). Phylogenetic analysis of fiber-associated rumen bacterial community and PCR detection of uncultured bacteria, FEMS Microbiol. Lett., 229: 23-30.

[18] Forsberg, C. W., Cheng, K. J., and White, B. A. "Polysaccharide degradation in the rumen and large intestine" in Gastrointestinal Microbiology, Mackie, R. I., and White, B. A. Eds. Chapman and Hall, New York, 1997, pp. 319-379.

[19] Fondevila, M. and Dehority, B. A. (1996). Interactions between Fibrobacter succinogenes, Prevotella ruminicola, and Ruminococcus flavefaciens in the digestion of cellulose from forages, J. Anim. Sci., 74: 678-684.

[20] Sawanon, S., Koike, S., and Kobayashi, Y. (2011). Evidence for the possible involvement of Selenomonas ruminantium in rumen fiber digestion, FEMS Microbiol. Lett., 325: 170-179.

[21] Kudo, H., Cheng, K. J., and Costerton, J. W. (1987). Interactions between Treponema bryantii and cellulolytic bacteria in the in vitro degradation of straw cellulose, Can. J. Microbiol., 33: 244-24.
[22] Goad, D. W., Goad, C. L., and Naganya, T. G. (1998). Ruminai microbial and fermentative changes associated with experimentally induced subacute acidosis in steers, J. Anim. Sci., 76: 234-241.

[23] Kim, J. N., Méndez-García1, C., Geier, R. R. Iakiviak, M., Chang, J., Cann, I., and Mackie, R. I. (2017). Metabolic networks for nitrogen utilization in Prevotella ruminicola 23, Sci. Rep., 7: 1-11.

[24] Rodriguez, F. (2003). Control of lactate accumulation in ruminants using Prevotella bryantii. PhD Thesis. Iowa State University, Ames.

[25] Chiquette, J., Allison, M. J., and Rasmussen, M. A. (2008). Prevotella bryantii $25 \mathrm{~A}$ used as a probiotic in early-lactation dairy cows: effect on ruminal fermentation characteristics, milk production, and milk composition1, J. Dairy Sci., 91: 3536-3543.

[26] Russell, J. B. and Hino, T. (1985). Regulation of lactate production in Streptococcus bovis: A spiraling effect that contributes to rumen acidosis, J. Dairy Sci., 68: 1712-1721.

[27] Nagaraja, T. G. and Titgemeyer, E. C. (2007). Ruminal acidosis in beef cattle: The current microbiological and nutritional outlook, J. Dairy Sci., 90: 17-38.

[28] Station, T. B. (1984). Glucose metabolism of Treponema bryantii, an anaerobic rumen spirochete, Can. J. Microbiol., 30: $526-531$.

[29] Prins, R. A., Lankhorst, A., van der Meer, P,. Van Nevel, C. J. (1975). Some characteristics of Anaerovibrio lipolytica a rumen lipolytic organism, Antonie van Leeuwenhoek, 41: 111.

[30] Louis, P., Duncan, S. H. McCrae, S. I., Millar, J., Jackson, M. S., and Flint, H. J. (2004). Restricted distribution of the butyrate kinase pathway among butyrate-producing bacteria from the human colon, J. Bacteriol., 186: 2099-2106.

[31] Singh, K. M., Tripathi, A. K., Pandya, P. R., Parnerkar, S., Kothari, R. K., and Joshi, C. G. (2013). Molecular genetic diversity and quantitation of methanogen in ruminal fluid of buffalo (Bubalus bubalis) fed ration (wheat straw and concentrate mixture diet), Genet. Res. Int., 2013: 1-7.

[32] Balch, W. E., Fox, G. E., Magrum, L. J., Woese, C. R., and Wolfe, R. S. (1979). Methanogens: Reevaluation of a unique biological group, Microbiol. Rev., 43: 260-296.

[33] Taherzadeh, M. J. and Karimi, K. (2008). Pretreatment of lignocellulosic wastes to improve ethanol and biogas production, Int. J. Mol. Sci., 9: 1621-1651.

[34] Russell, J. B. and Wilson, D. B. (1996). Why are ruminal cellulolytic bacteria unable to digest cellulose at low $\mathrm{pH}$, J. Dairy Sci., 79: 1503-1509.

[35] Wells, J. E. and Russell, J. B. (1996). Why do many ruminal bacteria die and lyse so quickly? J. Dairy Sci., 79: 147-1495. 